\title{
Application Timing of Aminocyclopyrachlor, Fluroxypyr, and Triclopyr Influences Swinecress Control in Tall Fescue
}

\author{
Thomas V. Reed ${ }^{1}$ and Patrick E. McCullough ${ }^{2,3}$ \\ Department of Crop and Soil Sciences, University of Georgia, 1109 \\ Experiment Street, Griffin, GA 30223-1797
}

Additional index words. temperature, weed control

\begin{abstract}
Swinecress [Coronopus didymus (L.) Sm.] is a problematic weed in newly seeded tall fescue (Festuca arundinacea Schreb.) and often warrants control with herbicides. The objective of this research was to investigate the influence of application timing on efficacy of aminocyclopyrachlor, fluroxypyr, and triclopyr for swinecress control compared with dichlorophenoxyacetic acid $(2,4-D)+3,6$-dichloro-o-anisic acid (dicamba) + methylchlorophenoxypropionic acid (MCPP). Aminocyclopyrachlor at 0.05 and $0.10 \mathrm{~kg}$ a.i./ha provided less than $35 \%$ control from February applications, but both rates averaged greater than $\mathbf{9 0 \%}$ control with April applications. Fluroxypyr at 0.26 and $0.52 \mathrm{~kg}$ a.i./ha provided poor (less than $\mathbf{7 0} \%$ ) control from February applications but control increased to $71 \%$ and $90 \%$ from April treatments, respectively. Triclopyr at 0.56 and $1.12 \mathrm{~kg}$ a.i./ha provided greater than $\mathbf{9 0 \%}$ swinecress control at both application timings and was comparable to 2,4-D + dicamba + MCPP. Overall, aminocyclopyrachlor and fluroxypyr were only effective for controlling swinecress in April, whereas triclopyr provided excellent control with February and April applications.
\end{abstract}

Swinecress [Coronopus didymus (L.) Sm.] is a winter annual broadleaf weed that may reduce quality of lawns and other turf areas. Swinecress has freely branched stems, deeply divided leaves, and spreading growth that compromise aesthetics of turfgrass stands (Radford et al., 1968). Swinecress tolerates heavy traffic, low mowing, and has prolific growth in turf areas with minimal competition (Harrington, 1992). For example, swinecress germination during cool-season turfgrass establishment in fall is difficult to manage and could warrant control with herbicides in winter or spring. However, swinecress control in turfgrass has received limited reporting in scientific literature and investigations are warranted to maximize efficacy of postemergence herbicides.

Aminocyclopyrachlor is a recently developed pyridine carboxylic acid herbicide for postemergence broadleaf weed control and is currently available in pastures and roadside grasses. Aminocyclopyrachlor has a chemical structure and mode of action similar to pyridine herbicides with efficacy for controlling annual and perennial broadleaf weeds (Minogue et al., 2011; Strachman et al., 2010). Pyridine herbicides such as fluroxypyr and triclopyr are effective for postemergence broadleaf weed control and are popular chemistries

Received for publication 2 July 2012. Accepted for publication 20 Aug. 2012.

${ }^{1}$ Graduate Assistant.

${ }^{2}$ Assistant Professor.

${ }^{3}$ To whom reprint requests should be addressed; e-mail pmccull@uga.edu. for cool-season turf (MacDonald et al., 1993; Neal, 1990). Efficacy of these herbicides may be affected by environmental conditions such as relative humidity, temperature, and soil moisture and applications often provide inconsistent broadleaf weed control in winter or early spring (Lubbers et al., 2007).

Environmental effects on plant growth and physiological processes may alter herbicide absorption, translocation, and metabolism (Richardson, 1977; Wanamarta and Penner, 1989). Plant responses to synthetic auxin herbicides may be influenced by environmental conditions before, during, and after applications (Barrier and Loomis, 1957). Additionally, translocation of pyridine herbicides has shown to increase with elevations in temperature suggesting efficacy of similar chemistries such as aminocyclopyrachlor could be affected by seasonal application timing for controlling broadleaf weeds such as swinecress (Radosevich and Bayer, 1979). The objective of this research was to evaluate the influence of application timing on efficacy of aminocyclopyrachlor, fluroxypyr, and triclopyr for controlling swinecress in tall fescue.

\section{Materials and Methods}

Field experiments were conducted at the University of Georgia in Griffin, GA, from February to June in 2011 and 2012. Soil was a Cecil loam with $2 \%$ organic matter and a $\mathrm{pH}$ of 6.0. Plots used in the 2012 experiment were adjacent to plots in 2011. In both years, fields were established in the previous fall by making two applications of glyphosate (Roundup Pro; Monsanto Co., St. Louis, MO) at $5 \mathrm{~kg}$ a.i./ha in September and then seeding 'Titan' tall fescue at $195 \mathrm{~kg} \cdot \mathrm{ha}^{-1}$ in October. Fields were irrigated to promote turf establishment. Tall fescue was mowed weekly at $6.4 \mathrm{~cm}$ height with clippings returned and irrigated as needed to prevent turfgrass wilt.

Treatments were the factorial combination of seven herbicides and two application timings. Herbicides applied included aminocyclopyrachlor (Imprelis 2SL; E.I. du Pont de Nemours and Co., Wilmington, DE) at 0.05 or $0.10 \mathrm{~kg}$ a.i./ha, fluroxypyr (Spotlight 1.5SL; Dow AgroSciences LLC, Indianapolis, IN) at 0.26 or $0.52 \mathrm{~kg}$ a.i./ha, triclopyr (Turflon Ester 4SL; Dow AgroSciences LLC) at 0.56 or $1.12 \mathrm{~kg}$ a.i./ha, and $2,4-\mathrm{D}+$ dicamba + MCPP (Trimec Classic 2.7SL; PBI Gordon Corp., Kansas City, MO) at $1.11+$ $0.12+0.3 \mathrm{~kg}$ a.i./ha. Herbicide treatments were applied by making two passes with a $\mathrm{CO}_{2}$-pressured backpack sprayer with a single 9504E flat-fan nozzle calibrated to deliver $374 \mathrm{~L} \cdot \mathrm{ha}^{-1}$ of spray volume. Application timings were 16 Feb. or 20 Apr. in 2011 and 13 Feb. or 9 Apr. in 2012. Swinecress groundcover on the day of treatments in February averaged $56 \%$ and $26 \%$ in 2011 and 2012, respectively. Swinecress groundcover on the day of treatments in April averaged 65\% and $53 \%$ in 2011 and 2012, respectively.

The experimental design was a randomized complete block with four replications of $1 \times 3-\mathrm{m}$ plots. Swinecress control was visually rated on a percent scale where 0 equaled no control and 100 equaled complete control. Tall fescue injury was visually rated on a percent scale where 0 equaled no injury and 100 equaled completely dead turf. Evaluations were made 2,4 , and 8 weeks after treatments (WAT). Swinecress had completely died out of all plots at 8 WAT from the April application timing in 2011, and thus only 2012 data are presented for this evaluation date. Data were subjected to analysis of variance at the $0.05 P$ level. Means were separated with Fisher's protected least significant difference test at $\alpha=0.05$. Year-by-treatment interactions were not detected and, thus, years were combined.

\section{Results and Discussion}

Tall fescue injury was not detected on any evaluation date (data not shown). Herbicide by application timing interactions were detected on every date and, thus, results are presented across all possible treatments (Table 1). Aminocyclopyrachlor at 0.05 and $0.1 \mathrm{~kg}$ a.i./ha provided less than $35 \%$ control from February applications, but efficacy increased with April applications as both rates averaged $90 \%$ control by 4 WAT. Aminocyclopyrachlor provided comparable swinecress control to 2,4-D + dicamba + MCPP at the April application timing on all dates but was less effective with February treatments.

Fluroxypyr applied in February provided poor (less than 70\%) swinecress control throughout the experiment (Table 1). However, April applications were more effective, and the $0.52 \mathrm{~kg}$ a.i./ha rate provided $90 \%$ 
control at 8 WAT. Fluroxypyr at $0.26 \mathrm{~kg}$ a.i./ha applied in April controlled swinecress $71 \%$ at 4 WAT, but control did not improve from this evaluation. Although efficacy increased at warmer temperatures in spring, fluroxypyr does not appear to be a standalone herbicide for swinecress control and may require repeat applications or tank mixtures with other synthetic auxins.

Triclopyr provided greater than $90 \%$ swinecress control at both application timings and was similar to 2,4-D + dicamba + MCPP at 8 WAT (Table 1). Although triclopyr applied at both timings provided excellent swinecress control at 8 WAT, efficacy was faster when applied under warmer temperatures in spring compared with winter. April applications of triclopyr provided $82 \%$ and $94 \%$ control by 4 WAT at 0.56 and $1.12 \mathrm{~kg}$

Table 1. Swinecress control in 'Titan' tall fescue after herbicide applications at two timings in field experiments, 2011-2012, Griffin, GA.

\begin{tabular}{|c|c|c|c|c|c|}
\hline \multirow[b]{3}{*}{ Timing $^{\mathrm{y}}$} & \multirow[b]{3}{*}{ Herbicide $^{w}$} & \multirow{3}{*}{$\begin{array}{c}\text { Rate } \\
\text { (kg a.i./ha) }\end{array}$} & \multicolumn{3}{|c|}{ Swinecress control $(\mathrm{WAT})^{\mathrm{z}}$} \\
\hline & & & 2 & 4 & 8 \\
\hline & & & \multicolumn{3}{|c|}{ - } \\
\hline \multirow[t]{8}{*}{ February } & \multirow[t]{2}{*}{ Aminocyclopyrachlor } & 0.05 & 22 & 23 & 16 \\
\hline & & 0.10 & 25 & 34 & 33 \\
\hline & \multirow[t]{2}{*}{ Fluroxypyr } & 0.26 & 26 & 25 & 24 \\
\hline & & 0.52 & 33 & 49 & 53 \\
\hline & \multirow[t]{2}{*}{ Triclopyr } & 0.56 & 33 & 63 & 94 \\
\hline & & 1.12 & 38 & 69 & 97 \\
\hline & 2,4-D + dicamba + MCPP & $1.11+0.12+0.30$ & 39 & 79 & 97 \\
\hline & \multicolumn{2}{|c|}{ February $\operatorname{LSD}_{0.05}$} & 5 & 11 & 14 \\
\hline \multirow[t]{9}{*}{ April } & \multirow[t]{2}{*}{ Aminocyclopyrachlor } & 0.05 & 65 & 94 & $96^{x}$ \\
\hline & & 0.10 & 53 & 88 & 87 \\
\hline & \multirow[t]{2}{*}{ Fluroxypyr } & 0.26 & 46 & 71 & 65 \\
\hline & & 0.52 & 57 & 80 & 90 \\
\hline & \multirow[t]{2}{*}{ Triclopyr } & 0.56 & 62 & 82 & 96 \\
\hline & & 1.12 & 63 & 94 & 100 \\
\hline & 2,4-D + dicamba + MCPP & $1.11+0.12+0.30$ & 64 & 95 & 100 \\
\hline & \multicolumn{2}{|c|}{ April LSD 0.05} & NS & 12 & 11 \\
\hline & \multicolumn{2}{|c|}{ Overall $\mathrm{LSD}_{0.05}$} & 16 & 11 & 14 \\
\hline
\end{tabular}

${ }^{2} \mathrm{WAT}=$ weeks after treatment.

'Treatments were applied on 16 Feb. and 20 Apr. in 2011 and 13 Feb. and 9 Apr. in 2012.

${ }^{\mathrm{x}}$ Swinecress had completely died out in all plots after 8 weeks for the April timing in 2011 and data presented are from 2012 only.

"Products applied were Imprelis 2SL (aminocyclopyrachlor), E.I. du Pont de Nemours and Co., Wilmington, DE; Spotlight 1.5SL (fluroxypyr), Dow AgroSciences LLC, Indianapolis, IN; Turflon Ester 4SL (triclopyr) Dow AgroSciences LLC; and Trimec Classic 2.7SL (2,4-D + dicamba + MCPP), PBI Gordon Corp., Kansas City, MO.

$\mathrm{MCPP}=$ methylchlorophenoxypropionic acid; LSD $=$ least significant difference.

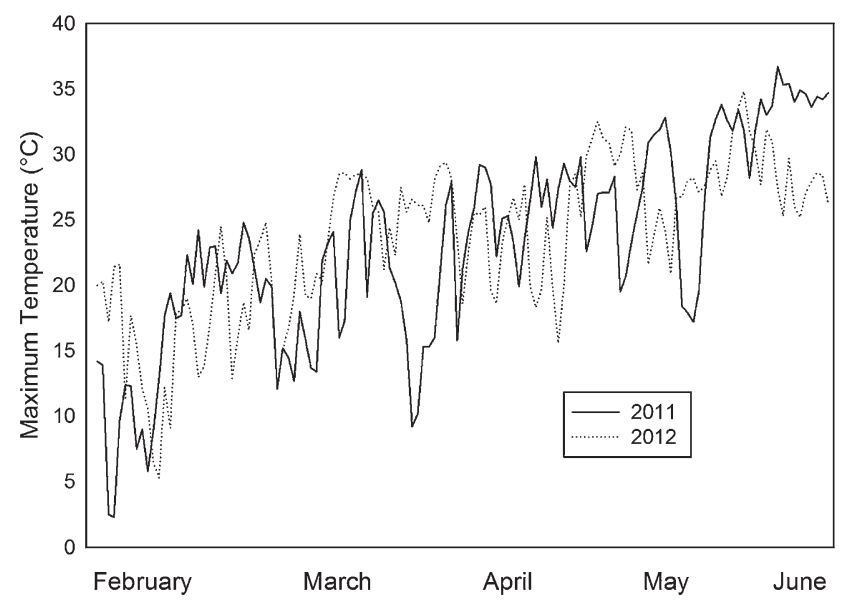

Fig. 1. Daily high air temperatures for Griffin, GA, during the experimental period in 2011 and 2012. triclopyr or 2,4-D + dicamba + MCPP. These results are consistent with previous reports of reductions in efficacy of synthetic auxins in cool weather from less absorption and mobility in targeted weeds (Lym and Messersmith, 1990; Radosevich and Bayer, 1979).

Finally, swinecress is a problematic weed that may reduce quality and establishment of newly seeded tall fescue. Synthetic auxin herbicides appear safe and effective for swinecress control in tall fescue but application timing is critical for maximizing efficacy. Despite excellent safety to tall fescue, aminocyclopyrachlor and fluroxypyr were not effective in controlling swinecress with winter applications. Spring applications of these herbicides provided good ( $80 \%$ to $89 \%$ ) to excellent ( $90 \%$ or greater) swinecress control suggesting aminocyclopyrachlor and fluroxypyr efficacy is temperature-dependent for winter and spring applications. Triclopyr was effective for controlling swinecress at both application timings and was less affected by low temperatures suggesting end-users may achieve better results with winter applications of triclopyr compared with aminocyclopyrachlor and fluroxypyr.

\section{Literature Cited}

Barrier, G.E. and W.E. Loomis. 1957. Absorption and translocation of 2,4- dichlorophenoxyacetic acid and P32 by leaves. Plant Physiol. 32: 225-231.

Harrington, K. 1992. Twin cress and wart cress N.Z. Turf Mgt. J. 6:37-38.

Lubbers, M.D., P.W. Stahlman, and K. Al-Khatib. 2007. Fluroxypyr efficacy is affected by relative humidity and soil moisture. Weed Sci. 55: 260-263.

Lym, R.G. and C.G. Messersmith. 1990. Effect of temperature on picloram absorption and translocation in leafy spurge (Euphobia esula). Weed Sci. 38:471-474.

MacDonald, R.T., J.C. Hall, J.J. O'Toole, and C.J. Swanton. 1993. Field bindweed (Convolvulus arvensis) control with fluroxypyr. Weed Technol. 7:966-971.

Minogue, P.J., S.F. Enloe, A. Osiecka, and D.K. Lauer. 2011. Comparison of aminocyclopyrachlor to common herbicides for kudzu (Pueraria montana) management. Invasive Plant Sci. and Mgt. 4:419-426.

Neal, J.C. 1990. Non-phenoxy herbicides for perennial broadleaf weed control in cool-season turf. Weed Technol. 4:555-559.

Radford, A.E., H.E. Ahles, and C.R. Bell. 1968 Manual of the vascular flora of the Carolinas. Univ. of North Carolina Press, Chapel Hill, NC.

Radosevich, S.R. and D.E. Bayer. 1979. Effect of temperature and photoperiod on tricolpyr, picloram, and 2,45-T translocation. Weed Sci. 27:22-27.

Richardson, R.G. 1977. A review of foliar absorption and translocation of 2,4-D and 2,4,5-T. Weed Res. 17:259-272.

Strachman, S.D., M.S. Casini, K.M. Heldreth, J.A. Scocas, S.J. Wissen, B. Bukun, R.B Lindenmayer, D.L. Shaner, P. Westra, and G. Brunk. 2010. Vapor movement of synthetic auxin herbicides: Aminocyclopyrachlor, aminocyclopyrachlor-methyl ester, dicamba, and aminopyralid. Weed Sci. 58:103-108.

Wanamarta, G. and D. Penner. 1989. Foliar absorption of herbicides. Rev. Weed Sci. 4:215231. 